\title{
How to bring absolute sustainability into decision-making: An industry case study using a Planetary Boundary-based methodology
}

Ryberg, Morten W.; Owsianiak, Mikoaj; Clavreul, Julie; Mueller, Carina; Sim, Sarah; King, Henry; Hauschild, Michael Zwicky

\section{Published in:}

Science of the Total Environment

Link to article, DOI:

10.1016/j.scitotenv.2018.04.075

Publication date:

2018

Document Version

Peer reviewed version

Link back to DTU Orbit

Citation (APA):

Ryberg, M. W., Owsianiak, M., Clavreul, J., Mueller, C., Sim, S., King, H., \& Hauschild, M. Z. (2018). How to bring absolute sustainability into decision-making: An industry case study using a Planetary Boundary-based methodology. Science of the Total Environment, 634, 1406-1416. https://doi.org/10.1016/j.scitotenv.2018.04.075

\section{General rights}

Copyright and moral rights for the publications made accessible in the public portal are retained by the authors and/or other copyright owners and it is a condition of accessing publications that users recognise and abide by the legal requirements associated with these rights.

- Users may download and print one copy of any publication from the public portal for the purpose of private study or research.

- You may not further distribute the material or use it for any profit-making activity or commercial gain

- You may freely distribute the URL identifying the publication in the public portal 
Ryberg MW, Owsianiak M, Clavreul J, et al. (2018) How to bring absolute sustainability into decision-making: An industry case study using a Planetary Boundary-based methodology. Sci Total Environ 634C:1406-1416. doi: https://doi.org/10.1016/j.scitotenv.2018.04.075

\section{How to bring absolute sustainability into decision-making: An industry}

\section{case study using a Planetary Boundary-based methodology}

Morten W Ryberg ${ }^{1 *}$, Mikołaj Owsianiak ${ }^{1}$, Julie Clavreul ${ }^{2}$, Carina Mueller ${ }^{2}$, Sarah $\mathrm{Sim}^{2}$, Henry King $^{2}$ and Michael Z Hauschild ${ }^{1}$

${ }^{1}$ Division for Quantitative Sustainability Assessment, Department of Management Engineering, Technical University of Denmark, Bygningstorvet, Building 116b, 2800 Kgs. Lyngby, Denmark

${ }^{2}$ Safety and Environmental Assurance Centre (SEAC), Unilever, Colworth Park, Sharnbrook, Bedford, UK

${ }^{*}$ Corresponding author: $\underline{\text { moryb@dtu.dk }}$ 
Ryberg MW, Owsianiak M, Clavreul J, et al. (2018) How to bring absolute sustainability into decision-making: An industry case study using a Planetary Boundary-based methodology. Sci Total Environ 634C:1406-1416. doi: https://doi.org/10.1016/j.scitotenv.2018.04.075

\section{Abstract}

The Planetary Boundaries concept has emerged as a framework for articulating environmental limits, gaining traction as a basis for considering sustainability in business settings, government policy and international guidelines. There is emerging interest in using the Planetary Boundaries concept as part of life cycle assessment (LCA) for gauging absolute environmental sustainability. We tested the applicability of a novel Planetary Boundaries-based life cycle impact assessment methodology on a hypothetical laundry washing case study at the EU level. We express the impacts corresponding to the control variables of the individual Planetary Boundaries together with a measure of their respective uncertainties. We tested four sharing principles for assigning a share of the safe operating space (SoSOS) to laundry washing and assessed if the impacts were within the assigned SoSOS. The choice of sharing principle had the greatest influence on the outcome. We therefore highlight the need for more research on the development and choice of sharing principles. Although further work is required to operationalize Planetary Boundaries in LCA, this study shows the potential to relate impacts of human activities to environmental boundaries using LCA, offering company and policy decisionmakers information needed to promote environmental sustainability.

\section{Keywords:}

Life cycle assessment; Life cycle impact assessment; Safe operating space 
Ryberg MW, Owsianiak M, Clavreul J, et al. (2018) How to bring absolute sustainability into decision-making: An industry case study using a Planetary Boundary-based methodology. Sci Total Environ 634C:1406-1416. doi: https://doi.org/10.1016/j.scitotenv.2018.04.075

\section{Introduction}

Many companies have articulated targets and strategies for sustainable business in recent years, aware of environmental limits which constrain resource use and Earth's capacity to assimilate emissions and wastes. Indeed, companies are increasingly referencing these environmental boundaries in their corporate reporting (Bjørn et al., 2016) and science strategies (Sim et al., 2016), perhaps indicating the beginning of a shift in emphasis from incremental, relative sustainability to absolute sustainability (Bjørn et al., 2015). Motivation for this may differ between companies but, broadly speaking, relates to three key areas: facilitating sustained business growth in the context of environmental limits, mitigating business risks (regulatory, reputational and resource) associated with transgressing these limits and minimizing the costs of doing business to ensure competitiveness (Bansal and Roth, 2000; Bonini and Görner, 2010; Lingard, 2012; Windolph et al., 2014). The Planetary Boundaries (PB) concept (Rockström et al., 2009a; Steffen et al., 2015b) has emerged as a key framework for articulating environmental limits, gaining traction as a scientific basis for sustainability in business settings, government policy and international guidelines (Clift et al., 2017; Galaz et al., 2012; Sim et al., 2016). For example, Action2020, led by the World Business Council for Sustainable Development, a global, CEO-led organization of over 200 leading businesses, has set a roadmap for sustainable business action based on the PB-concept (WBCSD, 2010). The PB-framework proposes quantitative boundaries for human pressures on key Earth System processes to maintain the planet in a stable Holocene-like state. Respecting all PBs would greatly reduce the risk of anthropogenic pressures pushing the Earth System into a much less hospitable state for humans (Steffen et al., 2015b). Indeed, interdependencies between Earth System processes suggest that transgressing one boundary could threaten our ability to stay within the safe operating space for others (Rockström et al., 2009b). For this reason, the PB-framework takes a 'strong' (Dobson, 1996) perspective on environmental sustainability, indicating the need to stay within all of the PBs as opposed to accepting substitutability and trade-offs between them. The specific measures and position of each boundary still require 
Ryberg MW, Owsianiak M, Clavreul J, et al. (2018) How to bring absolute sustainability into decision-making: An industry case study using a Planetary Boundary-based methodology. Sci Total Environ 634C:1406-1416. doi: https://doi.org/10.1016/j.scitotenv.2018.04.075

additional work and validation (Clift et al., 2017; Steffen et al., 2015b). However, the PB-framework is an attractive proposition for decision-making because it captures multiple global environmental pressures within one integrated framework and offers quantitative targets (boundaries) to support decision-making and action (Galaz et al., 2012); moreover, the definitions of the PBs are science-based and in principle neutral towards human values and aspiration since the mechanisms for staying within the safe operating space are not specified (Biermann, 2012). Where to set the PB limits within their respective uncertainty ranges is a normative choice and the PB-framework adopts a precautionary approach by setting the PBs at the low end of the uncertainty range and thereby maximizes the chance of respecting the Earth System (Rockström et al., 2009b). The PB-concept has already been used to assess human activities at both national and territorial scales (e.g. Dao et al., 2015; Fang et al., 2015; Fanning and O'Neill, 2016; Nykvist et al., 2013; O'Neill et al., 2018; Teah et al., 2016) and some LCA researchers have started to advocate using the PB-concept in an LCA-context (Bjørn et al., 2015; Hauschild, 2015). LCA is a standardized method for quantifying the environmental impacts of a product or service (EC-JRC, 2010; ISO, 2006a, 2006b). The calculated environmental impacts are often compared to those of similar products or services (i.e. internal normalization) or the 'background' impacts associated with a large anthropogenic system (i.e. external normalization) (ISO, 2006b; Laurent, 2015). LCA is thus a 'relative' sustainability assessment as the environmental performance of the system under study is evaluated by comparing the impacts with those of a reference system e.g., a product performing environmentally better than existing products are relatively more sustainable (Hauschild, 2015). Advocates of applying the PB-concept within the LCA framework argue that relating impact scores of products or services to absolute environmental boundaries offers an indication of the environmental sustainability of the product or service, in absolute terms (Bjørn et al., 2015; Hauschild, 2015).

In order to evaluate the absolute environmental sustainability of a product or service, a share of the safe operating space (SoSOS) needs to be defined and assigned to the product or service. An activity can only be 
Ryberg MW, Owsianiak M, Clavreul J, et al. (2018) How to bring absolute sustainability into decision-making: An industry case study using a Planetary Boundary-based methodology. Sci Total Environ 634C:1406-1416. doi: https://doi.org/10.1016/j.scitotenv.2018.04.075

considered sustainable if it does not exceed its assigned share (Bjørn et al., 2015). Procedures for assigning a SoSOS to a specific product or service will be normative (Vanderheiden, 2009) and are key to operationalizing the PB-concept for decision-making (Bjørn et al., 2015; Häyhä et al., 2016; Ryberg et al., 2016). The choice of sharing principle is a key determinant in the assessment of absolute sustainability and will influence the resulting decision-making (Ryberg et al., 2016; Sandin et al., 2015). Theories relating to distributive justice theory are relevant in this context (e.g. Banuri et al., 1996; Caney, 2009; Dworkin, 1981a, 1981b; Grasso, 2012; Moreno-Ternero and Roemer, 2012; Rawls, 1999; Rose et al., 1998; Vanderheiden, 2009; see Supplementary material (SM) 1 Section S1 for an extended description of distributive justice theory on distribution of ecological spaces).

\subsection{Methods for applying the Planetary Boundaries framework in Life Cycle Assessment}

A number of LCA methods for implementing the PB-framework into LCA have been developed. Tuomisto et al. (2012) developed weighting factors based on the distance between the current position of the Earth System process control variable and the PBs as defined by Rockström et al. (2009). Bjørn and Hauschild (2015) developed carrying capacity based normalization references (NRs) for the impact categories recommended by ILCD (EC-JRC, 2011) expressed as an equal 'per capita' annual budget of the carrying capacity. The NRs were partly based on the PBs, but instead of using the PBs, the average of the lower and upper bound of the 'zone of uncertainty' (Rockström et al., 2009b) was estimated and assumed to express the carrying capacity of the Earth System process (Bjørn and Hauschild, 2015). Doka $(2016,2015)$ developed a life cycle impact assessment (LCIA) method (PBA'06) with characterization factors (CFs) that expressed impacts as a fraction of the annual per capita allowance for each of the eight implemented PBs (Doka, 2016). Most recently, Ryberg et al. (2018) developed an LCIA methodology (referred to as PB-LCIA) which included the global and regional boundaries in the PB-framework by Steffen et al. (2015a). The results of the characterization models in the PB-LCIA method 
Ryberg MW, Owsianiak M, Clavreul J, et al. (2018) How to bring absolute sustainability into decision-making: An industry case study using a Planetary Boundary-based methodology. Sci Total Environ 634C:1406-1416. doi: https://doi.org/10.1016/j.scitotenv.2018.04.075

are expressed directly in the metrics of the PBs' control variables (e.g. ocean acidification is expressed as the change in aragonite saturation state).

A number of LCA case studies have assessed anthropogenic activities relative to the PBs. Sandin et al. (2015) derived reduction targets for a country's textile sector; Brejnrod et al. (2017) assessed the absolute sustainability of dwelling buildings; and Wolff et al. (2017) assessed the absolute sustainability of a company with a specific focus on biodiversity (see SM1 Section S2 for a more detailed description of the previously conducted studies). A common feature for all studies was that they matched the metrics of the PBs with existing impact categories in LCA. This approach can be problematic as there is a general misalignment in the scope and impact pathways between existing LCA impact category indicators and the control variables of the PB-framework (Laurent and Owsianiak, 2017; Ryberg et al., 2016).

The problems related to matching PBs with existing impact categories in LCA can be resolved by applying LCIA methods where the characterization models are specifically developed to express impact scores in the metrics of the PBs, such as the new PB-LCIA method developed by Ryberg et al. (2018). Furthermore, directly expressing results in the metrics of the PBs could ease communication of results to decision-makers who are already familiar with the PB-framework, but not necessarily familiar with the different impact categories that exist in LCA (Ryberg et al., 2018). In order to assess the feasibility and relevance of the PB-LCIA method, we conducted a hypothetical case study of laundry washing in the EU. The case study was considered hypothetical because laundry washing at the EU scale was extrapolated from data relating to a single 'model' liquid detergent product with a bio-based surfactant system. We did not consider other detergent products and the wide range of consumer habits across the EU. This allowed us to simplify the assessment whilst also investigating the sensitivity of the PB approach relating to land-system change and biogeochemical flows (due to the bio-based surfactant system). The specific objectives of the laundry case study were to: 
Ryberg MW, Owsianiak M, Clavreul J, et al. (2018) How to bring absolute sustainability into decision-making: An industry case study using a Planetary Boundary-based methodology. Sci Total Environ 634C:1406-1416. doi: https://doi.org/10.1016/j.scitotenv.2018.04.075

1. Evaluate the application of the PB-LCIA methodology and the use of different sharing principles;

2. Test the sensitivity of the approach (PB-LCIA and assigning a SoSOS) to capture effects of potential system changes;

3. Identify opportunities for further development of absolute sustainability assessment methods.

\section{Materials and methods}

\subsection{Laundry washing case study}

A case study on laundry washing in the EU was defined based on the current EU market where about 34.3

billion laundry washes are done per year (A.I.S.E., 2014). The functional unit (FU) was defined as "doing 34.3

billion washes per year of $4.5 \mathrm{~kg}$ of normally soiled dry fabric at medium water hardness with a model liquid

detergent". The specific FU was defined for several reasons: 1) the large scale allows for easier interpretation of absolute results; 2 ) assigning a SoSOS can be done more easily on a larger scale, rather than on the specific product level where more choices are required for partitioning (Ryberg et al., 2016); 3) the PB-LCIA requires annual elementary flows in the inventory.

The LCA was conducted in accordance with the requirements of the ISO standard and the guidelines of the International Reference Life Cycle Data System (ILCD) handbook (EC-JRC, 2010; ISO, 2006b). The decision context for this study was defined as 'accounting of environmental impacts' (referred to as situation C1 in the ILCD handbook); hence, the life cycle inventory (LCI) was modelled using an attributional modelling approach. Thus, processes representing the actual physical flows of the activity were used. All background data were based on ecoinvent v3 (Weidema et al., 2013) and the product system was modeled in SimaPro version 8.2.3.0. A full overview of all unit processes used for modelling the foreground system is found in SM2. Further, the default attributional system model of ecoinvent v3 (Weidema et al., 2013) was used for modelling the LCl. This 
Ryberg MW, Owsianiak M, Clavreul J, et al. (2018) How to bring absolute sustainability into decision-making: An industry case study using a Planetary Boundary-based methodology. Sci Total Environ 634C:1406-1416. doi: https://doi.org/10.1016/j.scitotenv.2018.04.075

includes using average supply of products rather than supply of non-constrained products (e.g. average electricity was used) and economic allocation was applied for converting multi-product datasets to singleproduct datasets. For instance, as crude palm oil production produces both palm oil and palm kernel oil (PKO), economic allocation was used to determine the share of the impacts from crude palm oil production that should be allocated to PKO production.

\subsubsection{Life cycle impact assessment}

The environmental impact scores for the case study were calculated using the PB-LCIA method as described by Ryberg et al. (2018). The PB-LCIA includes characterization models for the global and sub-global PBs in Steffen et al. (2015a) amounting to 15 impact categories in total (see Table 1). Only the PBs 'change in biosphere integrity' and 'introduction of novel entities' were excluded because a PB is yet to be defined for 'introduction of novel entities' while 'change in biosphere integrity' was excluded due to insufficient knowledge about the effect of anthropogenic pressures on biodiversity, and a lack of models to adequately characterize the causeeffect relationship between anthropogenic pressures and changes in biosphere integrity (Ryberg et al., 2018, 2016). It should be noted that not all PBs are analogous to the mid- and end-point thinking applied within LCA. For some PBs, e.g. land- system change, there may be overlap with others in terms of protection goals e.g. change in biosphere integrity and climate change. It is important to be aware of such overlaps when interpreting the results and essentially treat each impact category separately (Ryberg et al., 2016) as the overall goal is that the assigned SoSOS is respected across all impact categories. Only impact categories related to the Earth System components identified in the PB-framework were included and other life cycle impact categories often used in traditional LCAs, such as human toxicity, that are not linked to PBs are excluded.

The PB-LCIA method differs from traditional LCIA methodologies since the life cycle inventory information on resource use and emissions to the environment are given as mass per year (in contrast to conventional LCIAs 
Ryberg MW, Owsianiak M, Clavreul J, et al. (2018) How to bring absolute sustainability into decision-making: An industry case study using a Planetary Boundary-based methodology. Sci Total Environ 634C:1406-1416. doi: https://doi.org/10.1016/j.scitotenv.2018.04.075

where information is given as mass). This difference has several advantages compared to the other methods that have previously attempted to implement the PB-framework into LCA. First, by applying model inputs as mass per year, it is possible to express the results directly in terms of the metrics of the PB's control variables, i.e. as annual pressures or environmental states in a long-term (steady state) perspective (Ryberg et al., 2018). As a result, an anthropogenic entity which is found to be absolutely sustainable using the PB-LCIA method can be considered sustainable relative to the PBs over an infinite time-horizon and will not threaten to destabilize the current Holocene-like state (Ryberg et al., 2018). Second, by including the time perspective (i.e. per year) in the input to the LCIA, the choice related to assigning a SoSOS to the activity has been made more transparent and can be freely selected by the LCA-practitioner. This is in contrast to the previous studies (Bjørn and Hauschild, 2015; Doka, 2016) which only used mass as input to the LCIA and, therefore, had to express results as annual personal shares in order to account for the time perspective. Hence, the SoSOS was pre-assigned using an equal per capita sharing principle which removed the possibility for applying and testing other sharing principles.

\subsubsection{System description}

The laundry washing system was simplified by assuming European average washing habits and the use of a single type of detergent containing $100 \%$ bio-based surfactants. Simplified system boundaries are shown in Figure 1. They include the processes required for fulfilling the FU from extraction and supply of raw materials for producing the laundry detergent through the use phase to end-of-life (EoL), where washing water is treated in a wastewater treatment plant (WWTP). Default values (average or best-estimate) were used for modelling washing habits, electricity use, waste water treatment etc. Since Europe was selected as the primary geographical scope, a European average grid mix was assumed for all electricity and heat used in Europe i.e. for detergent production, laundry washing and EoL processes (see SM1 Table S1 and Table S2). 
Ryberg MW, Owsianiak M, Clavreul J, et al. (2018) How to bring absolute sustainability into decision-making: An industry case study using a Planetary Boundary-based methodology. Sci Total Environ 634C:1406-1416. doi: https://doi.org/10.1016/j.scitotenv.2018.04.075

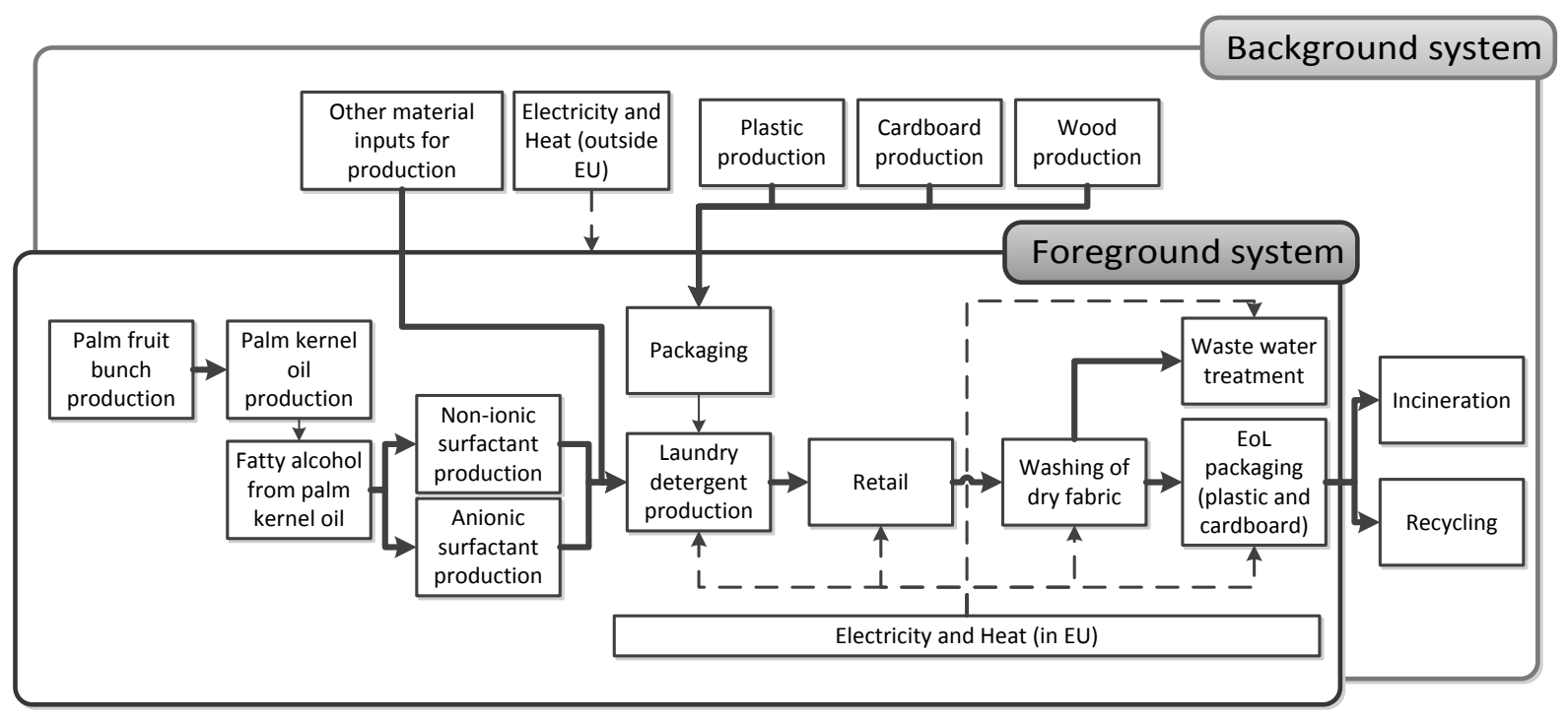

Figure 1. Simplified system boundaries for case study on laundry washing in the European Union. Solid lines are mass flows, dotted lines are flows of electricity and/or heat.

Raw materials required to produce the detergent were assumed to be globally traded and, therefore, modelled as global production. The bio-based anionic and non-ionic surfactants were assumed to be produced from fatty alcohol based on PKO, equating to approximately 0.24 million tonnes PKO per year. This corresponds to approximately $4 \%$ of global annual PKO production (Palm Oil Research, 2014). The PB-framework includes four PBs for land-system change, i.e. global forest area, and three PBs related to biome specific forest area (i.e. tropic, temperate, and boreal). The ecoinvent $\mathrm{LCl}$ database does not differentiate land transformation into forest biomes, however, information on the biomes affected by land-transformation are needed for characterizing impacts on the biome specific PBs. Hence the $\mathrm{LCl}$ foreground system specifies which forest biomes would be affected based on knowledge about the predominant forest biome in the affected locations. Tropical forest is affected by palm oil related activities as these occur in tropical forest areas (Olson et al., 2001; Ramankutty and Foley, 1999). Other activities of the life-cycle occurring in the EU were assumed to affect temperate forest as this is the dominant forest biome in the EU (Olson et al., 2001; Ramankutty and Foley, 
Ryberg MW, Owsianiak M, Clavreul J, et al. (2018) How to bring absolute sustainability into decision-making: An industry case study using a Planetary Boundary-based methodology. Sci Total Environ 634C:1406-1416. doi: https://doi.org/10.1016/j.scitotenv.2018.04.075

1999). For the detergent use, all washes were assumed to be done with a $4.5 \mathrm{~kg}$ load at $40^{\circ} \mathrm{C}$ (A.I.S.E, 2015). All wastewater, including detergent, was assumed to be discharged to the sewer after each wash and treated in a WWTP where emissions to the environment were estimated using the WWTP specific LCI model 'WWTP LCl' (Muñoz, 2015). The detergent packaging is made from plastic and board. $40 \%$ of the plastic and $84 \%$ of the board was modeled as recycled at EoL (Eurostat, 2014); the rest was assumed to be incinerated (Eurostat, 2017).

\subsection{Defining the share of the safe operating space}

The first step in assessing the SoSOS is to define the size of the safe operating space that should be distributed between all anthropogenic activities. In this study, the size of safe operating space available for human activities was defined as the value of the PB minus the 'natural background level' (i.e. the value of the control variable before human activities began affecting the Earth System process, referred to as the full safe operating space) (see Table 1). This definition enables a consistent approach to be applied when assigning a share of the full safe operating space to existing or planned activities. If the SoSOS assigned to an activity is not exceeded then it can be considered 'absolutely sustainable' in the sense that the activity acts within its assigned operating space and cannot be considered responsible for potential exceedance of the full safe operating space which on the other hand is a result of other activities not acting within their assigned operating space. In the case of the PBs which are currently not exceeded, if all activities stay within their assigned share of the full safe operating space this would ensure that the PBs would not, at some point in the future, be exceeded. For the PBs where the boundary has currently been exceeded (e.g. climate change) then if all activities reduce their contribution to a level that does not exceed their assigned share, it is possible to reduce and maintain pressures associated with anthropogenic activities within the safe operating space, assuming that previous boundary transgression has remained within the zone of uncertainty and has not already generated abrupt or 
Ryberg MW, Owsianiak M, Clavreul J, et al. (2018) How to bring absolute sustainability into decision-making: An industry case study using a Planetary Boundary-based methodology. Sci Total Environ 634C:1406-1416. doi: https://doi.org/10.1016/j.scitotenv.2018.04.075

irreversible environmental change. For instance, if all activities reduced their $\mathrm{CO}_{2}$ emissions from current levels

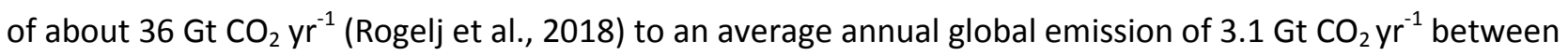
2000 and 2300, this would reduce atmospheric $\mathrm{CO}_{2}$ concentrations to about 361 ppm by 2300 (Meinshausen et al., 2011; Ryberg et al., 2018), which is very close to the PB of 350 ppm atmospheric $\mathrm{CO}_{2}$.

An alternative option for defining the safe operating space is to use the remaining safe operating space (i.e. the PB minus the current value of the control variable. This approach was not used as it suffers from a number of fundamental flaws which, in the worst case, can discourage a transition towards an environmentally sustainable society. The remaining safe operating space is not relevant for evaluating how an existing or planned activity can affect humanity's ability to maneuver within the total safe operating space. Instead, the definition is only relevant for showing if the introduction of a new activity will lead to exceedance of the PBs, assuming everything else remains the same. Use of the remaining safe operating space, essentially pre-assigns the already occupied share of the full safe operating space to existing activities according to a 'status quo' sharing principle, while new and perhaps environmentally better performing activities are left to distribute the remaining share of the safe operating space. For PBs that have already been exceeded, the situation is even more pronounced. Here, the remaining safe operating space becomes negative and all new technologies with positive net-pressures on the environment would be found to be absolutely unsustainable, even if these pressures are smaller than those exerted by existing and equivalent technologies.

Table 1. The Planetary Boundary value and the natural background levels as given from Steffen et al. (2015) and references therein. The full safe operating space for humanity estimated as the PB minus the natural background level is shown in the last column.

\begin{tabular}{|l|c|c|c|c|}
\hline Impact category & Unit & $\begin{array}{c}\text { Planetary Boundary } \\
\text { (Steffen et al. 2015) }\end{array}$ & $\begin{array}{c}\text { Natural background level } \\
\text { (Steffen et al. 2015 and references therein) }\end{array}$ & $\begin{array}{c}\text { Full safe operating } \\
\text { space }\end{array}$ \\
\hline Climate change - Energy imbalance & $\mathrm{Wm}^{-2}$ & 1 & 0 & 1 \\
\hline Climate change $-\mathrm{CO}_{2}$ concentration & $\mathrm{ppm} \mathrm{CO}_{2}$ & 350 & 278 & 72 \\
\hline
\end{tabular}


Ryberg MW, Owsianiak M, Clavreul J, et al. (2018) How to bring absolute sustainability into decision-making: An industry case study using a Planetary Boundary-based methodology. Sci Total Environ 634C:1406-1416. doi: https://doi.org/10.1016/j.scitotenv.2018.04.075

\begin{tabular}{|l|c|c|c|c|}
\cline { 2 - 5 } Stratospheric ozone depletion & $\mathrm{DU}$ & 275 & 290 & 15 \\
\hline Ocean acidification & $\mathrm{mol}$ & 2.75 & 3.44 & 0.69 \\
\hline Biogeochemical flows - P, regional & $\mathrm{Tg} \mathrm{P} \mathrm{yr}^{-1}$ & 26.2 & 20 & 6.2 \\
\hline Biogeochemical flows - N, global & $\mathrm{Tg} \mathrm{N} \mathrm{yr}^{-1}$ & 62 & 100 & 62 \\
\hline Land-system change - Global & $\%$ & 75 & 100 & 25 \\
\hline Land-system change - Boreal & $\%$ & 85 & 100 & 15 \\
\hline Land-system change - Tropic & $\%$ & 85 & 100 & 50 \\
\hline Land-system change - Temperate & $\%$ & 50 & 0 & 4000 \\
\hline Freshwater use - Global & $\mathrm{km}^{3} \mathrm{yr}^{-1}$ & 4000 & 0 & 1 \\
\hline Freshwater use - Basin dry & - & 1 & 0 & 1 \\
\hline Freshwater use - Basin semidry & - & 1 & 0 & 1 \\
\hline Freshwater use - Basin humid & - & 1 & 0.14 & \\
\hline Atmospheric aerosol loading & - & 0.25 & & 0.11 \\
\hline
\end{tabular}

Four different principles for assigning the SoSOS were applied in the case study (Table 2). These approaches were chosen to illustrate the sensitivity of the PB-LCIA method and outcome to the choice of sharing principle. A comparison was made between three egalitarian sharing principles and one non-egalitarian sharing principle. The status quo sharing principle in which the SoSOS for laundry washing in the EU is proportional to its current contribution to environmental impacts was selected as the non-egalitarian sharing principle (Grasso, 2012)

When applying an egalitarian sharing principle previous studies have shown that a strict per capita approach is not sufficient for determining the SoSOS that should be assigned to a company or an activity (Brejnrod et al., 2017; Sandin et al., 2015; Wolff et al., 2017). In line with Brejnrod et al. (2017) and Wolff et al. (2017), we assigned a SoSOS based on economic indicators. This was done under the assumption that economic value can be considered a proxy for contribution to human wellbeing, i.e. increased economic value leading to increased wellbeing. The economic value is, thus, related to welfare-based egalitarianism as defined by Dworkin (1981a). In line with Brejnrod et al. (2017) and Ryberg et al. (2016) two sharing principles were defined based on final consumption expenditure (FCE) which expresses consumer preferences for the activity under study. FCE was treated as a proxy for citizen preferences i.e., a preference for expenditure on laundry washing rather than other activities. 
Ryberg MW, Owsianiak M, Clavreul J, et al. (2018) How to bring absolute sustainability into decision-making: An industry case study using a Planetary Boundary-based methodology. Sci Total Environ 634C:1406-1416. doi: https://doi.org/10.1016/j.scitotenv.2018.04.075

The first FCE-based sharing principle (called 'FCE only') related FCE on laundry washing in the EU to total global FCE. FCE on laundry washing includes expenses for the detergent product, electricity, and water used during laundry washing. The second FCE-based sharing principle (called 'EU per cap \& FCE'), initially applied a percapita sharing principle for assigning a share of the full safe operating space to the EU population, then FCE on laundry washing in the EU was related to total FCE in the EU. This allowed for an assessment of the effects of performing an initial per-capita sharing principle. The third economic sharing principle was based on the contribution to gross value added (GVA) (called 'EU per cap \& GVA'). Again, an initial per-capita sharing principle was applied for assigning a share of the full safe operating space to the EU population and then a fraction was assigned to laundry washing reflecting the ratio between GVA related to laundry washing in the EU with total GVA in the EU. It should be noted that only GVA for washing detergents was used in the calculation because data on the GVA from electricity and water consumption specifically related to laundry washing were not available. Sharing principles based on two different economic indicators were applied to identify if there were differences in the assigned SoSOS, or if different economic indicators could be expected to assign similar SoSOS. Specific calculations for assigning the SoSOS are provided in SM1 Section S5. The sharing of the safe operating space was calculated according to Eq. 1.

$\operatorname{SoSOS}_{P B, S P}=S O S_{P B} \times a S_{P B, S P}$

where SoSOS sharing principle $(\mathrm{SP}), \mathrm{SOS}_{\mathrm{PB}}$ is the full safe operating space delimited by the $\mathrm{PB}$ and $\mathrm{aS}_{\mathrm{PB}, \mathrm{SP}}[\%]$ is the percentwise share assigned to the system under study according to the chosen sharing principle. Absolute environmental sustainability of a studied system can be assessed according to Eq. 2 .

$\operatorname{occSoSOS}_{P B, S P}=\frac{I S_{P B}}{\operatorname{SoSOS}_{P B, S P}}$ 
Ryberg MW, Owsianiak M, Clavreul J, et al. (2018) How to bring absolute sustainability into decision-making: An industry case study using a Planetary Boundary-based methodology. Sci Total Environ 634C:1406-1416. doi: https://doi.org/10.1016/j.scitotenv.2018.04.075

where occSoSOS sharing principle. $\mathrm{IS}_{\mathrm{PB}}$ is the characterized impact score for a $\mathrm{PB}$ in the PB-LCIA. If occSoSOS $\mathrm{PB}_{\mathrm{SP}}$ is equal to or less than one, then the studied system could be considered sustainable for the particular PB, given the chosen sharing principle. Ideally occSoSOS $\mathrm{PB}_{\mathrm{PP}}$ should be equal to or less than one across all PBs, to be fully environmentally sustainable and in compliance with a strong sustainability perspective. 
Ryberg MW, Owsianiak M, Clavreul J, et al. (2018) How to bring absolute sustainability into decision-making: An industry case study using a Planetary Boundary-based methodology. Sci Total Environ 634C:1406-1416. doi: https://doi.org/10.1016/j.scitotenv.2018.04.075

1 Table 2. Principles for estimating the share of the safe operating space assigned to laundry washing in the EU.

\begin{tabular}{|c|c|c|c|}
\hline Sharing principle & Equation & \multicolumn{2}{|c|}{$\begin{array}{l}\text { Share of safe operating space assigned to the studied } \\
\text { system }\left(\mathrm{a} \mathrm{S}_{\mathrm{PB}, \mathrm{SP}}\right)\end{array}$} \\
\hline $\begin{array}{l}\text { EU per cap \& FCE } \\
\text { (Egalitarian) }\end{array}$ & $\begin{array}{l}a S_{P B, S P}=\frac{P_{E U}}{P_{W o r l d}} \times \frac{F C E_{E U, \text { washing }}}{F C E_{E U}} \\
\text { Where a } \mathrm{PB}_{\mathrm{PB}, \mathrm{AP}} \text { is the share of the safe operating space assigned to the system under study. } \mathrm{P}_{\mathrm{EU}} \text { is the } \\
\text { population in the } \mathrm{EU}, \mathrm{P}_{\text {World }} \text { is the World population, } F \mathrm{FE}_{\mathrm{EU}} \text {, washing is the amount spent by consumer on } \\
\text { laundry washing (i.e. detergent product, electricity, water) in the } \mathrm{EU} \text {, and } F C E_{\mathrm{EU}} \text { is the total final } \\
\text { consumption expenditure of the } \mathrm{EU} \text {. }\end{array}$ & $0.018 \%$ & \\
\hline $\begin{array}{l}\text { FCE only } \\
\text { (Egalitarian) }\end{array}$ & $\begin{array}{l}a S_{P B, S P}=\frac{F C E_{E U, \text { washing }}}{F C E_{\text {World }}} \\
\text { Where } F C E_{\text {World }} \text { is the total global final consumption expenditure. }\end{array}$ & $0.039 \%$ & \\
\hline $\begin{array}{l}\text { EU per cap \& GVA } \\
\text { (Egalitarian) }\end{array}$ & $\begin{array}{l}a S_{P B, S P}=\frac{P_{E U}}{P_{W \text { orld }}} \times \frac{G V A_{E U, \text { washing }}}{G V A_{E U}} \\
\text { Where GVA } \\
\mathrm{GVA}_{\mathrm{EU}} \text { is washing is gross value added from laundry washing (detergent products only) in the EU, and } \\
\end{array}$ & $0.007 \%$ & \\
\hline $\begin{array}{l}\text { Status quo (Non- } \\
\text { egalitarian) }\end{array}$ & 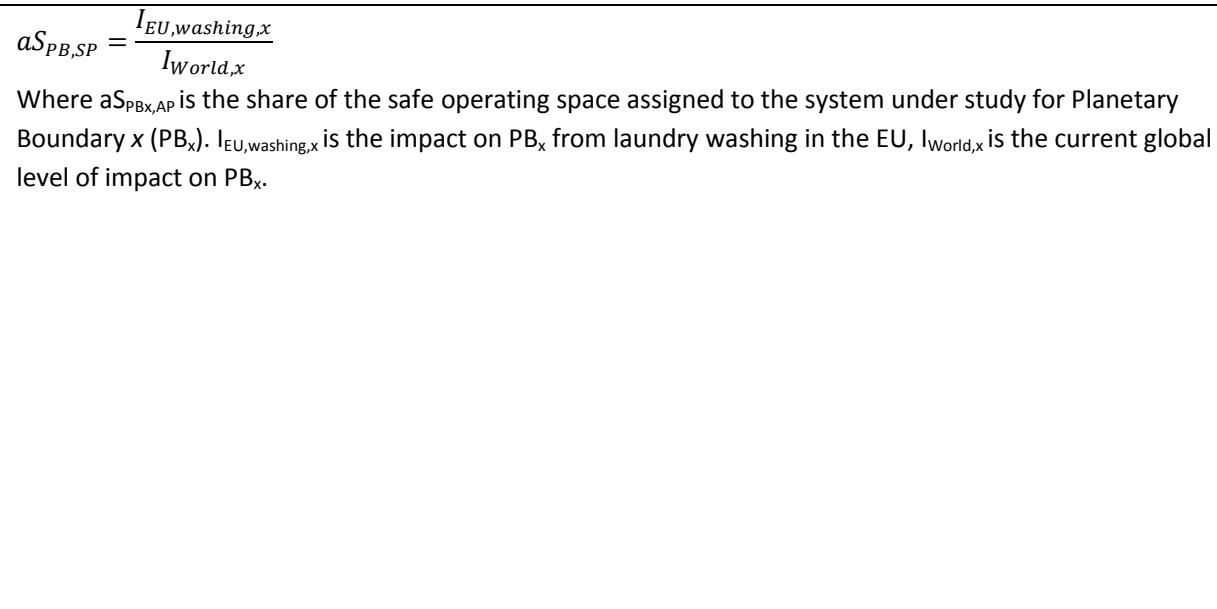 & $\begin{array}{l}\text { Climate change - Energy imbalance } \\
\text { Climate change - } \mathrm{CO}_{2} \text { concentration } \\
\text { Stratospheric ozone depletion } \\
\text { Ocean acidification } \\
\text { Biogeochemical flows - Regional P } \\
\text { Biogeochemical flows - } \mathrm{N} \\
\text { Land-system change - Global } \\
\text { Land-system change - Boreal } \\
\text { Land-system change - Tropic } \\
\text { Land-system change - Temperate } \\
\text { Freshwater use - Global } \\
\text { Freshwater use - Basin dry } \\
\text { Freshwater use - Basin semidry } \\
\text { Freshwater use - Basin humid } \\
\text { Atmospheric aerosol loading }\end{array}$ & $\begin{array}{l}0.25 \% \\
0.36 \% \\
0.00001 \% \\
0.24 \% \\
0.04 \% \\
0.09 \% \\
0.02 \% \\
0 \% \\
0.03 \% \\
0.00001 \% \\
0.06 \% \\
0.002 \% \\
0.0002 \% \\
0.70 \% \\
0.05 \%\end{array}$ \\
\hline
\end{tabular}


Ryberg MW, Owsianiak M, Clavreul J, et al. (2018) How to bring absolute sustainability into decision-making: An industry case study using a Planetary Boundary-based methodology. Sci Total Environ 634C:1406-1416. doi: https://doi.org/10.1016/j.scitotenv.2018.04.075

\subsection{Scenario analysis}

Seven potential system improvement options were defined (see Table 3) to evaluate the sensitivity of the PB-

LCIA approach in capturing their potential effect on the environmental performance of laundry washing in

Europe with current technologies. They are representative of the types of choices or options likely to be

considered by business or policy decision-makers. A best-case scenario \#8 was defined that combines all seven

7 improvement options.

8 Table 3. Overview of alternative scenarios for laundry washing in the EU

\begin{tabular}{|c|c|c|c|}
\hline Scenario & Scenario description & $\begin{array}{l}\text { Geographical } \\
\text { location affected }\end{array}$ & Change relative to baseline scenario parameters in Table S3 \\
\hline 1 & Baseline scenario & & No changes \\
\hline 2 & $\begin{array}{l}\text { EU low-carbon electricity mix based on higher } \\
\text { share of renewable energy sources (European } \\
\text { Commission, 2011), giving a } 75 \% \text { reduction in } \\
\text { emissions of } \mathrm{CO}_{2} \text {-eqs. }\end{array}$ & EU & $\begin{array}{l}\text { Current average EU electricity grid mix changed to projected EU } \\
\text { electricity grid mix in year } 2050 \text { (see SM1 Table S1) }\end{array}$ \\
\hline 3 & $\begin{array}{l}\text { Improvement in washing machine technology } \\
\text { which reduces energy use by } 10 \%\end{array}$ & EU & $\begin{array}{l}\text { Electricity use by washing machine per washing cycle, changed } \\
\text { from } 0.44 \mathrm{kWh} \text { per cycle to } 0.40 \mathrm{kWh} \text { per cycle. }\end{array}$ \\
\hline 4 & $\begin{array}{l}\text { Laundry washing done with cold water with an } \\
\text { energy consumption of } 0.15 \mathrm{kWh} \text { per cycle } \\
\text { (European Commission, 2002) instead of } 0.44 \mathrm{kWh} \\
\text { per cycle. }\end{array}$ & EU & $\begin{array}{l}\text { Corresponds to washing temperature of } 15^{\circ} \mathrm{C} \text { instead of } 40^{\circ} \mathrm{C} \text { in } \\
\text { the baseline scenario }\end{array}$ \\
\hline 5 & Increase in palm fresh fruit bunch yield [t/ha/year] & $\begin{array}{l}\text { Indonesia and } \\
\text { Malaysia }\end{array}$ & $\begin{array}{l}\text { Yield [t/ha/year] changed from } 16.9 \text { to } 36 \text { based on Hoffmann } \\
\text { et al. (Hoffmann et al., 2014) }\end{array}$ \\
\hline 6 & $\begin{array}{l}\text { Zero deforestation associated with palm oil and no } \\
\text { greenhouse gas emissions from land used change } \\
\text { (LUC) }\end{array}$ & $\begin{array}{l}\text { Indonesia and } \\
\text { Malaysia }\end{array}$ & Carbon emissions from land transformation are set to zero. \\
\hline 7 & $\begin{array}{l}\text { High yield and no deforestation for palm oil } \\
\text { production (scenarios } 5 \text { and } 6 \text { ) }\end{array}$ & $\begin{array}{l}\text { Indonesia and } \\
\text { Malaysia }\end{array}$ & $\begin{array}{l}\text { Yield equal to } 36 \mathrm{t} / \mathrm{ha} / \text { year } \\
\text { Zero carbon emission from land transformation }\end{array}$ \\
\hline 8 & A best-case scenario (scenarios 2 to 7 combined) & $\begin{array}{l}\text { EU and Indonesia } \\
\text { and Malaysia }\end{array}$ & \\
\hline
\end{tabular}

9

\subsection{Sensitivity and uncertainty analyses}


Ryberg MW, Owsianiak M, Clavreul J, et al. (2018) How to bring absolute sustainability into decision-making: An industry case study using a Planetary Boundary-based methodology. Sci Total Environ 634C:1406-1416. doi: https://doi.org/10.1016/j.scitotenv.2018.04.075

\subsubsection{Sensitivity analysis}

12

Parameters for the foreground LCl which were not well known and thus uncertain, and parameters which are inherently variable (e.g. palm fruit bunch yield and detergent dosage) are listed in SM1 Table S3. The sensitivity of the LCA result to these parameters was evaluated through a perturbation analysis (Heijungs, 2010). Parameters to which the LCA results of the baseline scenario (scenario \#1) were most sensitive were identified by calculating normalized sensitivity coefficients $\left(\mathrm{S}_{\text {coef }}\right)$, according to Eq. 3 (Heijungs, 2010; Yeh, 1986).

$$
S_{\text {coef }}=\frac{\Delta I S}{I S_{0}} / \frac{\Delta a_{k}}{a_{k, 0}}
$$

where $a_{k, 0}$ is the default input parameter value, $I S_{0}$ is the impact score calculated for the $a_{k, 0}, \Delta a_{k}$ is the difference between the default input parameter and the perturbed input parameter, $\Delta \mathrm{IS}$ is the difference between $\mathrm{IS}_{0}$ and the impact score calculated for the perturbed parameter value. All input parameters were perturbed by $10 \%$. For this study, the result was found to be sensitive for parameters with $\left|S_{\text {coef }}\right|>=0.05$ for at least one impact category, namely: palm replanting cycle, palm fruit bunch yield, washing temperature, detergent use per washing cycle, water use by washing machine per washing cycle, tropical forest carbon stock and oil palm carbon stock (SM1 Table S4).

\subsubsection{Uncertainty analysis}

For parameters with $\left|S_{\text {coef }}\right|>=0.05$, specific details about realistic value ranges were identified (see SM1 Table S3) to more accurately determine the associated parameter uncertainty. For the other parameters, a wide uncertainty range which includes the possibility of extreme values was assumed (i.e. squared geometric standard deviation $\left(\mathrm{GSD}^{2}\right)$ of 100$)$. All parameters were assumed log-normally distributed to ensure parameters were zero or positive and to allow for extreme value cases. The only exception was the recycling rate, which can be between $0 \%$ and $100 \%$; hence recycling was assigned a uniform probability distribution with a range 
Ryberg MW, Owsianiak M, Clavreul J, et al. (2018) How to bring absolute sustainability into decision-making: An industry case study using a Planetary Boundary-based methodology. Sci Total Environ 634C:1406-1416. doi: https://doi.org/10.1016/j.scitotenv.2018.04.075

from $0 \%$ to $100 \%$. Monte Carlo simulation was used to propagate uncertainty from the inventory results to the impact scores for each impact category and for each scenario.

\section{Results}

\subsection{Environmental impacts of laundry washing in the EU}

Results of the case study show how the PB-LCIA method can be used to express characterized impact scores aligned to the PBs and their control variables (Table 4). The characterized impact scores for the baseline scenario indicate that annual laundry washing in the EU under the modelled conditions would, for instance, lead to an atmospheric $\mathrm{CO}_{2}$ concentration of $0.43 \mathrm{ppm}$ which represents $0.6 \%$ of the safe operating space for climate change (Table 4). This is mainly due to emissions of fossil $\mathrm{CO}_{2}$, primarily from energy use during the use phase ( $65 \%$ of total impact), and $\mathrm{CO}_{2}$ emissions from land transformation ( $11 \%$ of total impact). Ocean acidification, biogeochemical flows - nitrogen, and tropical land-system change were also found to be important and all occupy more than $0.1 \%$ of the safe operating space. Ocean acidification is driven by $\mathrm{CO}_{2}$ emissions, as is climate change. Biogeochemical flows - nitrogen is driven by nitrate emissions resulting from fertilizer use during palm oil production and from the disposal of waste from lignite used in energy generation. Tropical land-system change is driven by the historical and any on-going transformation of tropical forest into oil palm plantations. Across the life cycle the major drivers of impacts are from the use stage (electricity and water use) and in the production of surfactants (land use and land management) for the detergent (see SM1 Figure S1).

The seven alternative scenarios generally resulted in an improved overall environmental performance, yielding up to $75 \%$ reduction in impacts relative to the baseline scenario (for climate change in scenario \#8 which combines all changes in scenarios 2-7). However, scenario \#2 resulted in larger impact scores than the baseline scenario due to the projected larger share of hydropower and bio-based electricity in the EU grid mix in 2050 
Ryberg MW, Owsianiak M, Clavreul J, et al. (2018) How to bring absolute sustainability into decision-making: An industry case study using a Planetary Boundary-based methodology. Sci Total Environ 634C:1406-1416. doi: https://doi.org/10.1016/j.scitotenv.2018.04.075

54 (see SM1 Table S1). The larger share of electricity from hydropower and wood biomass is associated with

55 increased freshwater use and forest area for electricity production compared to the baseline scenario. In

56 general, scenarios focusing on improved energy efficiency and increased electricity production from

57 renewables were more beneficial for climate related impact categories while scenarios focusing on improving

58 land use practice were more beneficial for reducing impacts related to land-system change and biogeochemical

59 flows. Scenario \#8 performed best for all impact categories, except 'Land-system change' where it ranked $3^{\text {rd }}$,

60 after scenario \#5 and \#7, because it included the switch to more bio-based electricity in the EU 2050 grid mix.

61 Overall, scenario \#8 reduced impacts between $19 \%$ and $75 \%$ relative to the baseline scenario. (SM1 Figure S1). 
Ryberg MW, Owsianiak M, Clavreul J, et al. (2018) How to bring absolute sustainability into decision-making: An industry case study using a Planetary Boundary-based methodology. Sci Total Environ 634C:1406-1416. doi: https://doi.org/10.1016/j.scitotenv.2018.04.075

\begin{tabular}{|c|c|c|c|c|c|c|c|c|c|}
\hline \multirow[b]{2}{*}{ Impact category } & \multirow[b]{2}{*}{ Unit } & \multicolumn{8}{|c|}{ Scenarios } \\
\hline & & $\# 1$ & $\# 2$ & $\# 3$ & $\# 4$ & $\# 5$ & \#6 & $\# 7$ & $\# 8$ \\
\hline $\begin{array}{l}\text { Climate change - Energy } \\
\text { imbalance }\end{array}$ & $\mathrm{Wm}^{-2}$ & $\begin{array}{c}5.8 \times 10^{-3} / 0.58 \% \\
(2.7)\end{array}$ & $\begin{array}{r}3.1 \times 10^{-3} / 0.31 \% \\
(2.4)\end{array}$ & $\begin{array}{r}5.4 \times 10^{-3} / 0.54 \% \\
(2.8)\end{array}$ & $\begin{array}{r}3.0 \times 10^{-3} / 0.30 \% \\
(2.2)\end{array}$ & $\begin{array}{r}5.3 \times 10^{-3} / 0.53 \% \\
(2.7)\end{array}$ & $\begin{array}{r}5.1 \times 10^{-3} / 0.51 \% \\
(2.5)\end{array}$ & $\begin{array}{r}5.0 \times 10^{-3} / 0.50 \% \\
(2.4)\end{array}$ & $\begin{array}{r}1.5 \times 10^{-3} / 0.15 \% \\
(1.5) \\
\end{array}$ \\
\hline $\begin{array}{l}\text { Climate change }-\mathrm{CO}_{2} \\
\text { concentration }\end{array}$ & $\begin{array}{l}\mathrm{ppm} \\
\mathrm{CO}_{2}\end{array}$ & $\begin{array}{r}4.3 \times 10^{-1} / 0.60 \% \\
(2.8) \\
\end{array}$ & $\begin{array}{r}2.2 \times 10^{-1} / 0.30 \% \\
(2.5) \\
\end{array}$ & $\begin{array}{r}4.0 \times 10^{-1} / 0.55 \% \\
(2.9) \\
\end{array}$ & $\begin{array}{r}2.2 \times 10^{-1} / 0.30 \% \\
(2.2) \\
\end{array}$ & $\begin{array}{r}4.0 \times 10^{-1} / 0.55 \% \\
(2.7) \\
\end{array}$ & $\begin{array}{r}3.8 \times 10^{-1} / 0.53 \% \\
(2.6) \\
\end{array}$ & $\begin{array}{r}3.7 \times 10^{-1} / 0.52 \% \\
(2.4) \\
\end{array}$ & $\begin{array}{r}1.1 \times 10^{-1} / 0.15 \% \\
(1.5) \\
\end{array}$ \\
\hline $\begin{array}{l}\text { Stratospheric ozone } \\
\text { depletion }\end{array}$ & DU & $\begin{array}{r}9.4 \times 10^{-6} / 0.00 \% \\
(3.5)\end{array}$ & $\begin{array}{r}7.0 \times 10^{-6} / 0.00 \% \\
(2.7)\end{array}$ & $\begin{array}{r}8.6 \times 10^{-6} / 0.00 \% \\
(4.1)\end{array}$ & $\begin{array}{r}3.9 \times 10^{-6} / 0.00 \% \\
(2.2)\end{array}$ & $\begin{array}{r}9.3 \times 10^{-6} / 0.00 \% \\
(3.8)\end{array}$ & $\begin{array}{r}9.4 \times 10^{-6} / 0.00 \% \\
(3.6)\end{array}$ & $\begin{array}{r}9.3 \times 10^{-6} / 0.00 \% \\
(3.6)\end{array}$ & $\begin{array}{r}3.1 \times 10^{-6} / 0.00 \% \\
(1.8)\end{array}$ \\
\hline Ocean acidification & $\mathrm{mol}$ & $\begin{array}{r}1.3 \times 10^{-3} / 0.19 \% \\
(2.8)\end{array}$ & $\begin{array}{r}6.7 \times 10^{-4} / 0.10 \% \\
(2.5)\end{array}$ & $\begin{array}{r}1.2 \times 10^{-3} / 0.18 \% \\
(2.9)\end{array}$ & $\begin{array}{r}6.7 \times 10^{-4} / 0.10 \% \\
(2.2)\end{array}$ & $\begin{array}{r}1.2 \times 10^{-3} / 0.18 \% \\
(2.7)\end{array}$ & $\begin{array}{r}1.2 \times 10^{-3} / 0.17 \% \\
(2.6)\end{array}$ & $\begin{array}{r}1.1 \times 10^{-3} / 0.17 \% \\
(2.4)\end{array}$ & $\begin{array}{r}3.3 \times 10^{-4} / 0.05 \% \\
(1.5)\end{array}$ \\
\hline $\begin{array}{l}\text { Biogeochemical flows - } \\
\text { P, regional }\end{array}$ & $\operatorname{Tg} P y^{-1}$ & $\begin{array}{r}5.6 \times 10^{-3} / 0.09 \% \\
(3.9)\end{array}$ & $\begin{array}{r}5.7 \times 10^{-3} / 0.09 \% \\
(2.1)\end{array}$ & $\begin{array}{r}5.5 \times 10^{-3} / 0.09 \% \\
(3.1)\end{array}$ & $\begin{array}{r}5.5 \times 10^{-3} / 0.09 \% \\
(2.2)\end{array}$ & $\begin{array}{r}3.4 \times 10^{-3} / 0.05 \% \\
(2.4)\end{array}$ & $\begin{array}{r}5.6 \times 10^{-3} / 0.09 \% \\
(4.9)\end{array}$ & $\begin{array}{r}3.4 \times 10^{-3} / 0.05 \% \\
(2.3)\end{array}$ & $\begin{array}{r}3.3 \times 10^{-3} / 0.05 \% \\
(2.0)\end{array}$ \\
\hline $\begin{array}{l}\text { Biogeochemical flows - } \\
\mathrm{N} \text {, global }\end{array}$ & $\operatorname{Tg}_{1}^{\mathrm{Tg} N \mathrm{yr}}$ & $\begin{array}{r}1.3 \times 10^{-1} / 0.21 \% \\
(2.0)\end{array}$ & $\begin{array}{r}8.7 \times 10^{-2} / 0.14 \% \\
(1.8)\end{array}$ & $\begin{array}{r}1.2 \times 10^{-1} / 0.20 \% \\
(2.1)\end{array}$ & $\begin{array}{r}8.6 \times 10^{-2} / 0.14 \% \\
(1.7)\end{array}$ & $\begin{array}{r}1.1 \times 10^{-1} / 0.17 \% \\
(2.2)\end{array}$ & $\begin{array}{r}1.3 \times 10^{-1} / 0.21 \% \\
(2.0)\end{array}$ & $\begin{array}{r}1.1 \times 10^{-1} / 0.17 \% \\
(2.1)\end{array}$ & $\begin{array}{r}5.1 \times 10^{-2} / 0.08 \% \\
(1.7)\end{array}$ \\
\hline $\begin{array}{l}\text { Land-system change - } \\
\text { Global }\end{array}$ & $\%$ & $\begin{array}{r}7.5 \times 10^{-3} / 0.03 \% \\
(2.1) \\
\end{array}$ & $\begin{array}{r}7.5 \times 10^{-3} / 0.03 \% \\
(2.1) \\
\end{array}$ & $\begin{array}{r}7.5 \times 10^{-3} / 0.03 \% \\
(2.1) \\
\end{array}$ & $\begin{array}{r}7.5 \times 10^{-3} / 0.03 \% \\
(2.1) \\
\end{array}$ & $\begin{array}{r}3.7 \times 10^{-3} / 0.01 \% \\
(2.1)\end{array}$ & $\begin{array}{r}7.5 \times 10^{-3} / 0.03 \% \\
(2.1) \\
\end{array}$ & $\begin{array}{r}3.7 \times 10^{-3} / 0.01 \% \\
(2.0) \\
\end{array}$ & $\begin{array}{r}3.7 \times 10^{-3} / 0.01 \% \\
(2.1) \\
\end{array}$ \\
\hline $\begin{array}{l}\text { Land-system change - } \\
\text { Tropic }\end{array}$ & $\%$ & $\begin{array}{r}2.1 \times 10^{-2} / 0.14 \% \\
(2.1) \\
\end{array}$ & $\begin{array}{r}2.1 \times 10^{-2} / 0.14 \% \\
(2.1) \\
\end{array}$ & $\begin{array}{r}2.1 \times 10^{-2} / 0.14 \% \\
(2.1) \\
\end{array}$ & $\begin{array}{r}2.1 \times 10^{-2} / 0.14 \% \\
(2.1) \\
\end{array}$ & $\begin{array}{r}1.0 \times 10^{-2} / 0.07 \% \\
(2.1) \\
\end{array}$ & $\begin{array}{r}2.1 \times 10^{-2} / 0.14 \% \\
(2.1) \\
\end{array}$ & $\begin{array}{r}1.0 \times 10^{-2} / 0.07 \% \\
(2.0) \\
\end{array}$ & $\begin{array}{r}1.1 \times 10^{-2} / 0.07 \% \\
(2.1) \\
\end{array}$ \\
\hline $\begin{array}{l}\text { Land-system change - } \\
\text { Temperate }\end{array}$ & $\%$ & $\begin{array}{r}2.6 \times 10^{-6} / 0.00 \% \\
(2.1) \\
\end{array}$ & $\begin{array}{r}1.4 \times 10^{-6} / 0.00 \% \\
(2.1) \\
\end{array}$ & $\begin{array}{r}2.4 \times 10^{-6} / 0.00 \% \\
(2.1) \\
\end{array}$ & $\begin{array}{r}1.3 \times 10^{-6} / 0.00 \% \\
(2.1) \\
\end{array}$ & $\begin{array}{r}2.5 \times 10^{-6} / 0.00 \% \\
(2.1) \\
\end{array}$ & $\begin{array}{r}2.6 \times 10^{-6} / 0.00 \% \\
(2.1) \\
\end{array}$ & $\begin{array}{r}2.5 \times 10^{-6} / 0.00 \% \\
(2.0) \\
\end{array}$ & $\begin{array}{r}8.5 \times 10^{-7} / 0.00 \% \\
(2.1) \\
\end{array}$ \\
\hline Freshwater use - Global & $\mathrm{km}^{3} \mathrm{yr}^{-1}$ & $1.5 / 0.04 \%(1.5)$ & $1.5 / 0.04 \%(1.6)$ & $\begin{array}{r}1.4 / 0.04 \% \\
(1.5)\end{array}$ & $1.5 / 0.04 \%(1.6)$ & $1.4 / 0.04 \%(1.6)$ & $\begin{array}{r}1.5 / 0.04 \% \\
(1.6)\end{array}$ & $\begin{array}{r}1.4 / 0.04 \% \\
(1.6)\end{array}$ & $\begin{array}{r}1.3 / 0.03 \% \\
(1.6)\end{array}$ \\
\hline $\begin{array}{l}\text { Freshwater use - Basin } \\
\text { dry }\end{array}$ & - & $\begin{array}{r}3.2 \times 10^{-6} / 0.00 \% \\
(1.8)\end{array}$ & $\begin{array}{r}3.9 \times 10^{-6} / 0.00 \% \\
(1.9) \\
\end{array}$ & $\begin{array}{r}3.0 \times 10^{-6} / 0.00 \% \\
(1.9)\end{array}$ & $\begin{array}{r}2.4 \times 10^{-6} / 0.00 \% \\
(1.6)\end{array}$ & $\begin{array}{r}3.0 \times 10^{-6} / 0.00 \% \\
(1.8)\end{array}$ & $\begin{array}{r}3.2 \times 10^{-6} / 0.00 \% \\
(1.8)\end{array}$ & $\begin{array}{r}3.0 \times 10^{-6} / 0.00 \% \\
(1.8)\end{array}$ & $\begin{array}{r}2.4 \times 10^{-6} / 0.00 \% \\
(1.5)\end{array}$ \\
\hline $\begin{array}{l}\text { Freshwater use - Basin } \\
\text { semidry }\end{array}$ & - & $\begin{array}{r}8.6 \times 10^{-7} / 0.00 \% \\
(1.7)\end{array}$ & $\begin{array}{r}1.0 \times 10^{-6} / 0.00 \% \\
(1.8)\end{array}$ & $\begin{array}{r}8.2 \times 10^{-7} / 0.00 \% \\
(1.8)\end{array}$ & $\begin{array}{r}7.0 \times 10^{-7} / 0.00 \% \\
(1.6)\end{array}$ & $\begin{array}{r}8.1 \times 10^{-7} / 0.00 \% \\
(1.9)\end{array}$ & $\begin{array}{r}8.6 \times 10^{-7} / 0.00 \% \\
(1.8)\end{array}$ & $\begin{array}{r}8.1 \times 10^{-7} / 0.00 \% \\
(1.7)\end{array}$ & $\begin{array}{r}6.8 \times 10^{-7} / 0.00 \% \\
(1.5)\end{array}$ \\
\hline $\begin{array}{l}\text { Freshwater use - Basin } \\
\text { humid }\end{array}$ & - & $\begin{array}{r}2.0 \times 10^{-4} / 0.02 \% \\
(3.3) \\
\end{array}$ & $\begin{array}{r}1.5 \times 10^{-4} / 0.02 \% \\
(3.2) \\
\end{array}$ & $\begin{array}{r}1.8 \times 10^{-4} / 0.02 \% \\
(3.3) \\
\end{array}$ & $\begin{array}{r}1.3 \times 10^{-4} / 0.01 \% \\
(1.2) \\
\end{array}$ & $\begin{array}{r}1.9 \times 10^{-4} / 0.02 \% \\
(1.9) \\
\end{array}$ & $\begin{array}{r}2.0 \times 10^{-4} / 0.02 \% \\
(3.1) \\
\end{array}$ & $\begin{array}{r}1.9 \times 10^{-4} / 0.02 \% \\
(3.0) \\
\end{array}$ & $\begin{array}{r}1.1 \times 10^{-4} / 0.01 \% \\
(1.2) \\
\end{array}$ \\
\hline $\begin{array}{l}\text { Atmospheric aerosol } \\
\text { loading }\end{array}$ & - & $\begin{array}{r}7.3 \times 10^{-5} / 0.07 \% \\
(2.0)\end{array}$ & $\begin{array}{r}5.2 \times 10^{-5} / 0.05 \% \\
(1.7)\end{array}$ & $\begin{array}{r}6.8 \times 10^{-5} / 0.06 \% \\
(2.0)\end{array}$ & $\begin{array}{r}4.6 \times 10^{-5} / 0.04 \% \\
(1.6)\end{array}$ & $\begin{array}{r}6.2 \times 10^{-5} / 0.06 \% \\
(2.1)\end{array}$ & $\begin{array}{r}7.3 \times 10^{-5} / 0.07 \% \\
(2.0)\end{array}$ & $\begin{array}{r}6.2 \times 10^{-5} / 0.06 \% \\
(2.0)\end{array}$ & $\begin{array}{r}3.0 \times 10^{-5} / 0.03 \% \\
(1.6)\end{array}$ \\
\hline
\end{tabular}


Ryberg MW, Owsianiak M, Clavreul J, et al. (2018) How to bring absolute sustainability into decision-making: An industry case study using a Planetary Boundary-based methodology. Sci Total Environ 634C:1406-1416. doi: https://doi.org/10.1016/j.scitotenv.2018.04.075

\subsection{Relating impact scores to a share of the safe operating space}

67

By assigning shares of the safe operating space to the studied system it was possible to relate the impact scores to the PB and estimate the absolute sustainability of laundry washing in the EU. Figure 2 shows how the impact scores for the baseline scenario (scenario \#1) of laundry washing today and for scenario \#8, which includes all improvement options, are related to the SoSOS for laundry washing assigned by the four sharing principles. For impact categories where the impact scores exceed the assigned SoSOS, it was possible to quantify the 'sustainability gap' (i.e. the distance between the impact scores and the assigned SoSOS) (Fang et al., 2015a), and the additional reductions required closing the gap to remain within the SoSOS. For example, scenario \#8 exceeded the assigned share for climate change for the three egalitarian approaches used to assign the SoSOS but not when using the status quo principle. For the cases where the SoSOS was exceeded, an impact reduction of a factor of 4 to 21 would be required to stay within the assigned share. Moreover, the results allow for the evaluation of the relative importance of the $\mathrm{LCl}$ uncertainty, uncertainty in the position of the PB (where the PB is positioned at the lower bound of the zone of uncertainty as described by Rockström et al., 2009b), and the uncertainty related to the choice of sharing principle. Generally, the assigned SoSOS varied by 2-3 orders of magnitude (although up to five orders of magnitude variation was found between sharing principles for some impact categories), whilst the LCl varied by about 1 order of magnitude, and the PB's zone of uncertainty varied by less than 1 order of magnitude. Hence, the uncertainty related to the choice of sharing principle has a larger influence on conclusions than $\mathrm{LCl}$ uncertainty and uncertainty related to position of the PB. The choice of sharing principle had the largest influence on whether impact scores exceeded or stayed within the assigned SoSOS for the following impact categories: climate change, ozone depletion, global and tropical land-system change, global freshwater use, freshwater use in humid regions, and atmospheric aerosol loading. 
Ryberg MW, Owsianiak M, Clavreul J, et al. (2018) How to bring absolute sustainability into decision-making: An industry case study using a Planetary Boundary-based methodology. Sci Total Environ 634C:1406-1416. doi: https://doi.org/10.1016/j.scitotenv.2018.04.075

\begin{tabular}{|ll|}
\hline W//Zone of uncertainty related to the Planetary Boundary & $\cdot$ Occupied share of assigned safe operating space \\
-- Planetary Boundary & $-95 \%$ conf. interval of impact scores \\
\hline
\end{tabular}
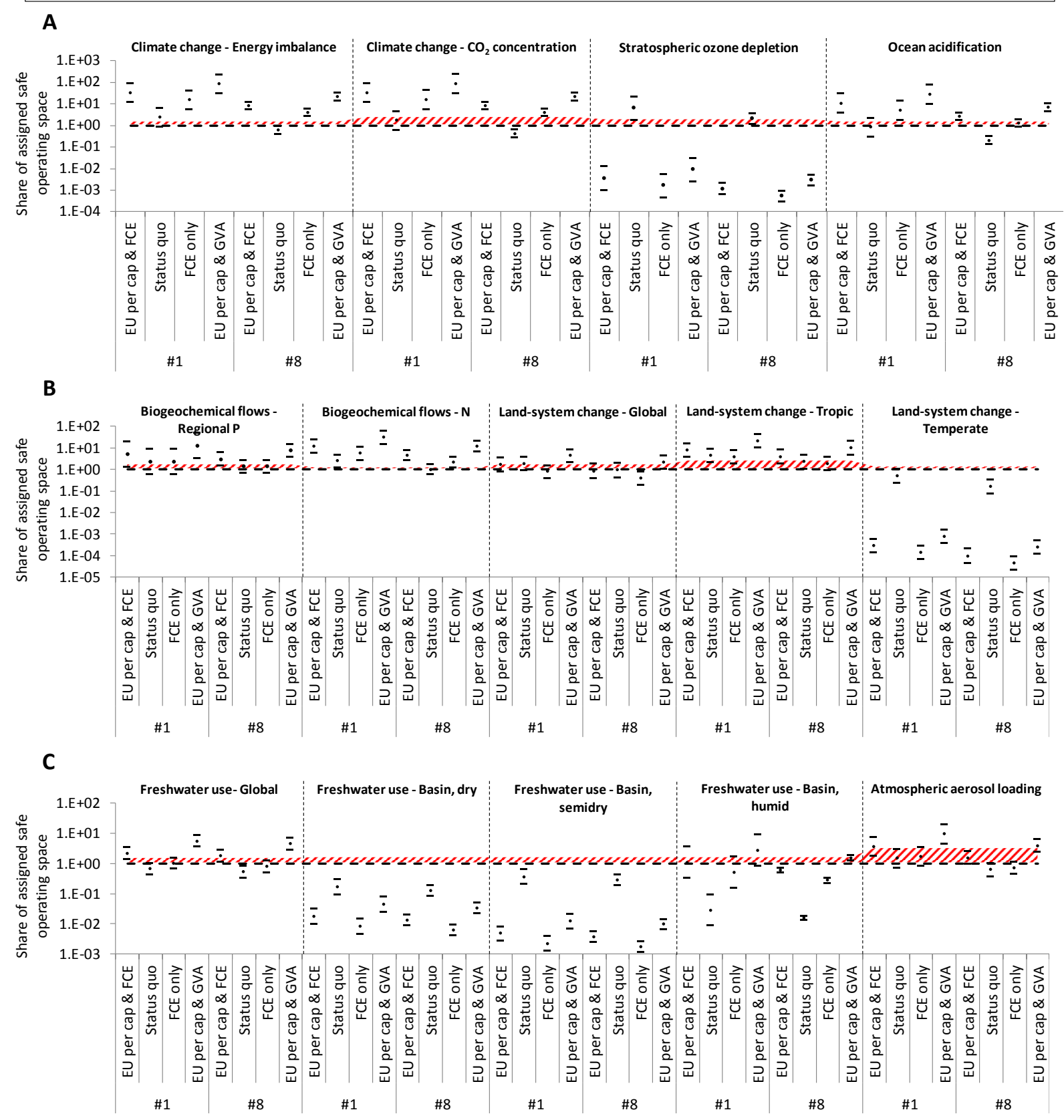

89 Figure 2. Impact scores and their 95\% confidence interval for laundry washing in the EU for scenario \#1 (baseline) and scenario \#8

90 (includes all changes), shown relative to the assigned share of the safe operating space calculated based on the four sharing principles.

91 Figure 2A shows Earth System processes with potential planetary thresholds that can affect sub-systems 'top down' (Rockström et al.,

92 2009b). Figure 2B and Figure 2C show Earth System processes where thresholds exceeded at local and regional scale can increase the

likelihood of crossing planetary thresholds in other Earth System processes, thus, affecting the Earth System 'bottom up' (Rockström et 
Ryberg MW, Owsianiak M, Clavreul J, et al. (2018) How to bring absolute sustainability into decision-making: An industry case study using a Planetary Boundary-based methodology. Sci Total Environ 634C:1406-1416. doi: https://doi.org/10.1016/j.scitotenv.2018.04.075

94

al., 2009b). The figure also includes the PBs' zone of uncertainty where thresholds for the Earth Systems are potentially located and where PBs are positioned at the lower bound of these zones. Note that Land-system change for boreal forest is excluded as all impact scores were zero for this subcategory.

\section{Discussion}

\subsection{Application of PB-LCIA methodology and approaches for sharing the safe operating space}

As shown in Table 4 and Figure 2, the results of the PB-LCIA methodology can be expressed either as characterized results or relative to an assigned SoSOS. The characterized results of the PB-LCIA can be used in the same way as characterized results in a conventional LCA, albeit they are not aligned to the current mid-and end-points used in impact assessment. The characterized results enable the evaluation of management choices or policy options in terms of their relative effect on the environmental performance. However, they do not provide an assessment of the absolute environmental sustainability of the system under study. By assigning a SoSOS and relating the impact scores to this share, it is possible to relate the impact scores to absolute limits and to identify whether any impacts exceed their assigned share. This capability provides the opportunity to devise reduction targets based on PBs and would help in the evaluation of reduction options based on their contribution to meeting sustainability goals at a societal level. However, it is clear from our case study that many levers for making environmental improvement in laundry washing lie outside the direct influence of individual producers or consumers. Many impacts of the laundry washing system were found to be associated with the wider production and consumption systems in the EU. Notably the current electricity grid mix which is heavily reliant on fossil fuels, resulting in relatively high contributions to the climate change boundary (Figure 2). Indeed, it is likely that most energy-using products would exceed their share of the safe operating space, simply because they rely on an underlying system that is unsustainable and on which they have no direct influence. This is well known and not a new insight. However, the added value of applying the PB-LCIA 
Ryberg MW, Owsianiak M, Clavreul J, et al. (2018) How to bring absolute sustainability into decision-making: An industry case study using a Planetary Boundary-based methodology. Sci Total Environ 634C:1406-1416. doi: https://doi.org/10.1016/j.scitotenv.2018.04.075

methodology is that it enables scaling or sizing of the necessary improvements required of the system by

industry, governments and citizens against objectively defined targets.

\subsection{Implications for assigning a share of the safe operating space}

There are many implications related to assigning a SoSOS to a specific activity since different sharing principles sharing principles to be used, a framework for considering this uncertainty in PB-LCA studies is needed. An approach could be to quantify the uncertainty related to the choice of sharing principle by applying Monte facilitate a consideration of uncertainty related to choice of sharing principle together with other sources of uncertainty, such as LCl-uncertainty. Here, a criterion for stating that an activity is 'absolutely' sustainable comparative LCAs (Huijbregts et al., 2003)) should not exceed the assigned SoSOS. 
Ryberg MW, Owsianiak M, Clavreul J, et al. (2018) How to bring absolute sustainability into decision-making: An industry case study using a Planetary Boundary-based methodology. Sci Total Environ 634C:1406-1416. doi: https://doi.org/10.1016/j.scitotenv.2018.04.075

137 There are several areas where further research is still required. As in the work of Sandin et al. (2015), this case 138 study also tested the sensitivity of the result to the choice of sharing principle for assigning a SoSOS. We also found that the choice of sharing principles was important. Our additional insight is that uncertainty of the result due to the choice of sharing principles exceeds uncertainty related to the $\mathrm{LCl}$ and the zone of uncertainty which related to the position of the PBs. Unless uncertainty related to $\mathrm{LCl}$ is extremely high, we see no reason why the choice of sharing principle would not also provide the largest source of uncertainty in other studies. Further research is, therefore, required to systematically identify and test a larger set of sharing principles and to provide recommendations for best practice. This should include identifying potential bias, and the availability of data to facilitate the application of the sharing principles in a way that is consistent with the physical system boundaries adopted for the study: e.g. economic information for all processes in the life cycle may be required if economic sharing principles are adopted. Given the normative nature of finding ways to share the safe operating space, we anticipate the need for interdisciplinary collaboration between researchers from natural science, social sciences, economics and humanities. In addition, when assigning a SoSOS, further consideration of the dynamic nature of production-consumption systems is required. The size of the assigned SoSOS will change over time, even if the PBs remain the same (which they will unless new scientific findings challenge their current placement), because the indicators used for assigning a SoSOS will change as a result of a continued development in population and anthropogenic activities over time. For instance, as the economy changes, e.g. through implementation of financial levers, technological development and demand trends, the size of the SoSOS that should be assigned to an activity will change. Such changes will require regular recalculation of the assigned SoSOS e.g., every fifth year as recommended for common NRs in LCA (Wenzel et al., 1997). Another option could be to derive the SoSOS based on external dynamic models that account for market mechanisms and consumer behavior. If such models were coupled with LCA, this would mean that assigned SoSOS were always up to date, reflecting the most recent developments in anthropogenic activities. 
Ryberg MW, Owsianiak M, Clavreul J, et al. (2018) How to bring absolute sustainability into decision-making: An industry case study using a Planetary Boundary-based methodology. Sci Total Environ 634C:1406-1416. doi: https://doi.org/10.1016/j.scitotenv.2018.04.075

\section{Conclusions}

161 In this study, we demonstrated the application of the PB-LCIA for absolute sustainability assessment of a

162 laundry washing case study in the EU. We showed that the PB-LCIA can be used to assess the absolute sustainability of products and technologies, providing guidance on the size of improvements needed for activities to remain within the PBs. This presents a first step in operationalizing PBs in absolute sustainability assessments using LCA where results are expressed in the metrics of the PBs. It is clear that various levers of change, in both the fore- and background systems, are required to reduce environmental impact of activities to levels within the assigned SoSOS. The largest source of uncertainty in our case study was found to be the choice of sharing principles for assigning a SoSOS, followed by LCl uncertainty and then uncertainty related to the position of PBs. Hence, an important research challenge is highlighted in relation to the choice of sharing principles. Nevertheless, this study shows the great potential of relating impacts of human activities to environmental boundaries in metrics that are consistent with the PBs, so that strategic actions and initiatives can be evaluated rapidly and objectively against environmental limits.

\section{Notes}

175 This research did not receive any specific grant from funding agencies in the public, commercial, or not-for176 profit sectors.

\section{Supplementary material}

179 Further details on methods and results are provided in Supplementary material 1. A complete overview of the life cycle inventory for modelling the case study is given in Supplementary material 2. 
Ryberg MW, Owsianiak M, Clavreul J, et al. (2018) How to bring absolute sustainability into decision-making: An industry case study using a Planetary Boundary-based methodology. Sci Total Environ 634C:1406-1416. doi: https://doi.org/10.1016/j.scitotenv.2018.04.075

181

182

\section{References}

183

184

185

186

187

188

189

190

191

192

193

194

195

196

197

198

199

200

A.I.S.E, 2015. PEF screening report in the context of the EU Product Environmental Footprint Category Rules (PEFCR) Pilots - Household Heavy Duty Liquid Laundry Detergents (HDLLD) for machine wash. CONFIDENTIAL. International Association for Soaps, Detergents and Maintenance Products.

A.I.S.E., 2014. Pan-European Consumer Survery On Sustainability and Washing Habits [summary of findings]. International Association for Soaps, Detergents and Maintenance Products.

Bansal, P., Roth, K., 2000. Why companies go green: A model of ecological responsivenes. Acad. Manag. J. 43, 717-736.

Banuri, T., Goran-Maler, K., Grubb, M., Jacobson, H.K., Yamin, F., 1996. Equity and Social Considerations, in: Bruce, J.P., Lee, H., Haites, E.F. (Eds.), Climate Change 1995. Economic and Social Dimensions of Climate Change. Contribution of Working Group III to the Second Assessment Report of the Intergovernmental Panel on Climate Change. Cambridge University Press, p. 339.

Biermann, F., 2012. Planetary boundaries and earth system governance: Exploring the links. Ecol. Econ. 81, 4-9.

Bjørn, A., Bey, N., Georg, S., Røpke, I., Hauschild, M.Z., 2016. Is Earth recognized as a finite system in corporate responsibility reporting? J. Clean. Prod. DOI: 10.1016/j.jclepro.2015.12.095.

Bjørn, A., Diamond, M., Owsianiak, M., Verzat, B., Hauschild, M.Z., 2015. Strengthening the Link between Life Cycle Assessment and Indicators for Absolute Sustainability To Support Development within Planetary Boundaries. Environ. Sci. Technol. 49, 6370-6371.

Bjørn, A., Hauschild, M.Z., 2015. Introducing carrying capacity-based normalisation in LCA: framework and 
Ryberg MW, Owsianiak M, Clavreul J, et al. (2018) How to bring absolute sustainability into decision-making: An industry case study using a Planetary Boundary-based methodology. Sci Total Environ 634C:1406-1416. doi: https://doi.org/10.1016/j.scitotenv.2018.04.075

development of references at midpoint level. Int. J. Life Cycle Assess. 20, 1005-1018.

202

Bonini, S., Görner, S., 2010. The business of sustainability: McKinsey Global Survey results [WWW Document]. URL http://www.mckinsey.com/business-functions/sustainability-and-resource-productivity/ourinsights/the-business-of-sustainability-mckinsey-global-survey-results (accessed 4.26.17).

Brejnrod, K.N., Kalbar, P., Petersen, S., Birkved, M., 2017. The absolute environmental performance of buildings. Build. Environ. 119, 87-98.

Caney, S., 2009. Justice and the distribution of greenhouse gas emissions. J. Glob. Ethics 5, 125-146.

Clift, R., Sim, S., King, H., Chenoweth, J., Christie, I., Clavreul, J., Mueller, C., Posthuma, L., Boulay, A.-M., Chaplin-Kramer, R., Chatterton, J., DeClerck, F., Druckman, A., France, C., Franco, A., Gerten, D., Goedkoop, M., Hauschild, M., Huijbregts, M., Koellner, T., Lambin, E., Lee, J., Mair, S., Marshall, S., McLachlan, M., Milà i Canals, L., Mitchell, C., Price, E., Rockström, J., Suckling, J., Murphy, R., 2017. The Challenges of Applying Planetary Boundaries as a Basis for Strategic Decision-Making in Companies with Global Supply Chains. Sustainability 9, 279.

Dao, H., Peduzzi, P., Chatenoux, B., De Bono, A., Schwarzer, S., Friot, D., 2015. Environmental limits and Swiss footprints based on Planetary Boundaries. Geneva, Switzerland.

Dobson, A., 1996. Environment sustainabilities: An analysis and a typology. Env. Polit. 5, 401-428.

Doka, G., 2015. Combining life cycle inventory results with planetary boundaries: The Planetary Boundary Allowance impact assessment method PBA'05. Doka LCA, Zürich.

Doka, G., 2016. Combining life cycle inventory results with planetary boundaries: The Planetary Boundary Allowance impact assessment method Update PBA'06. Doka Life Cycle Assessments, Zurich, Switzerland. 
Ryberg MW, Owsianiak M, Clavreul J, et al. (2018) How to bring absolute sustainability into decision-making: An industry case study using a Planetary Boundary-based methodology. Sci Total Environ 634C:1406-1416. doi: https://doi.org/10.1016/j.scitotenv.2018.04.075

221 Dworkin, R., 1981a. What is Equality? Part 1: Equality of Welfare. Philos. Public Aff. 10, 185-246.

222

Dworkin, R., 1981b. What is Equality? Part 2: Equality of Resources. Philos. Public Aff. 10, 283-345.

EC-JRC, 2010. General guide for life cycle assessment-detailed guidance. ILCD Handbook-International Reference Life Cycle Data System, First. ed, JRC, IES. European Union EUR 24708 EN. Publications Office of the European Union http://Ict.jrc.ec.europa.eu/, Luxembourg.

EC-JRC, 2011. ILCD Handbook- Recommendations for Life Cycle Impact Assessment in the European context, First. ed. European Commission - Joint Research Centre - Institute for Environment and Sustainability, Luxembourg.

European Commission, 2002. DEMAND-SIDE MANAGEMENT End-use metering campaign in 400 households of the European Community Assessment of the Potential Electricity Savings Project SAVE PROGRAMME. European Commision.

European Commission, 2011. Energy Roadmap 2050. Impact assessment and scenario analysis. European Commision.

Eurostat, 2014. Fraction of recycled packaging wastes at end-of-life : plastic packaging. 2014 data [WWW Document]. URL http://ec.europa.eu/eurostat/tgm/refreshTableAction.do;jsessionid=66vz4gR0M4ezXU8pENi2gWr7B4afzH9_ryZezLWykj3csX9xdje!-66628538?tab=table\&plugin=1\&pcode=ten00063\&language=fr (accessed 1.31.17).

Eurostat, 2017. Treatment of waste by waste category, hazardousness and waste operations [WWW Document]. URL http://appsso.eurostat.ec.europa.eu/nui/submitViewTableAction.do (accessed 7.16.17). 
Ryberg MW, Owsianiak M, Clavreul J, et al. (2018) How to bring absolute sustainability into decision-making: An industry case study using a Planetary Boundary-based methodology. Sci Total Environ 634C:1406-1416. doi: https://doi.org/10.1016/j.scitotenv.2018.04.075

241 Fang, K., Heijungs, R., De Snoo, G.R., 2015a. Understanding the complementary linkages between environmental footprints and planetary boundaries in a footprint-boundary environmental sustainability assessment framework. Ecol. Econ. 114, 218-226.

244

Fang, K., Heijungs, R., Duan, Z., De Snoo, G.R., 2015b. The Environmental Sustainability of Nations: Benchmarking the Carbon, Water and Land Footprints against Allocated Planetary Boundaries 1128511305.

Fanning, A.L., O’Neill, D.W., 2016. Tracking resource use relative to planetary boundaries in a steady-state framework : A case study of Canada and Spain. Ecol. Indic. 69, 836-849.

Galaz, V., Biermann, F., Folke, C., Nilsson, M., Olsson, P., 2012. Global environmental governance and planetary boundaries: An introduction. Ecol. Econ. 81, 1-3.

Grasso, M., 2012. Sharing the Emission Budget. Polit. Stud. 60, 668-686.

Hauschild, M.Z., 2015. Better - But is it Good Enough? On the Need to Consider Both Eco-efficiency and Ecoeffectiveness to Gauge Industrial Sustainability. Procedia CIRP 29, 1-7.

Häyhä, T., Lucas, P.L., van Vuuren, D.P., Cornell, S.E., Hoff, H., 2016. From Planetary Boundaries to national fair shares of the global safe operating space - How can the scales be bridged? Glob. Environ. Chang. 40, 6072.

Heijungs, R., 2010. Sensitivity coefficients for matrix-based LCA. Int. J. Life Cycle Assess. 15, 511-520.

Hoffmann, M.P., Castaneda Vera, A., van Wijk, M.T., Giller, K.E., Oberthür, T., Donough, C., Whitbread, A.M., 2014. Simulating potential growth and yield of oil palm (Elaeis guineensis) with PALMSIM: Model description, evaluation and application. Agric. Syst. 131, 1-10. 
Ryberg MW, Owsianiak M, Clavreul J, et al. (2018) How to bring absolute sustainability into decision-making: An industry case study using a Planetary Boundary-based methodology. Sci Total Environ 634C:1406-1416. doi: https://doi.org/10.1016/j.scitotenv.2018.04.075

261

262

263

264

265

266

267

268

269

270

271

272

273

274

275

276

277

278

279

280

Huijbregts, M.A.J., Gilijamse, W., Ragas, A.M.J., Reijnders, L., 2003. Evaluating uncertainty in environmental lifecycle assessment. A case study comparing two insulation options for a Dutch one-family dwelling. Environ. Sci. Technol. 37, 2600-8.

ISO, 2006a. ISO 14040: Environmental management - Life cycle assessment - Principles and framework, International Organization for Standardization.

ISO, 2006b. ISO 14044: Environmental management-Life cycle assessment-Requirements and guidelines, International Organization for Standardization. International Organization for Standardization.

Krabbe, O., Linthorst, G., Blok, K., Crijns-Graus, W., van Vuuren, D.P., Höhne, N., Faria, P., Aden, N., Pineda, A.C., 2015. Aligning corporate greenhouse-gas emissions targets with climate goals. Nat. Clim. Chang. 5, 1057-1060.

Laurent, A., 2015. Normalization, in: Hauschild, M., Huijbregts, M. (Eds.), Life Cycle Impact Assessment, LCA Compendium - The Complete World of Life Cycle Assessment. Springer-Science+Business Media, BV, Dordrecht, The Netherlands.

Laurent, A., Owsianiak, M., 2017. Potentials and limitations of footprints for gauging environmental sustainability. Curr. Opin. Environ. Sustain. 25, 20-27.

Lingard, T., 2012. Unilever's strategic response to sustainable development and its implications for public affairs professionals. J. Public Aff. 12, 224-229.

Meinshausen, M., Smith, S.J., Calvin, K., Daniel, J.S., Kainuma, M.L.T., Lamarque, J., Matsumoto, K., Montzka, S.A., Raper, S.C.B., Riahi, K., Thomson, A., Velders, G.J.M., van Vuuren, D.P.P., 2011. The RCP greenhouse gas concentrations and their extensions from 1765 to 2300. Clim. Change 109, 213-241. 
Ryberg MW, Owsianiak M, Clavreul J, et al. (2018) How to bring absolute sustainability into decision-making: An industry case study using a Planetary Boundary-based methodology. Sci Total Environ 634C:1406-1416. doi: https://doi.org/10.1016/j.scitotenv.2018.04.075

281

282

283

284

285

286

287

288

289

290

291

292

293

294

295

296

297

298

299

300

Moreno-Ternero, J.D., Roemer, J.E., 2012. A common ground for resource and welfare egalitarianism. Games Econ. Behav. 75, 832-841.

Muñoz, I., 2015. Wastewater life cycle inventory initiative. WWTP LCI tool user manual, version 1.0. 2.-0 LCA consultants, Aalborg.

Nykvist, B., Persson, Å., Moberg, F., Persson, L., Cornell, S., Rockström, J., 2013. National Environmental Performance on Planetary Boundaries. Swedish Environmental Protection Agency, Stockholm.

O’Neill, D.W., Fanning, A.L., Lamb, W.F., Steinberger, J.K., 2018. A good life for all within planetary boundaries. Nat. Sustain. 1, 88-95.

Olson, D.M., Dinerstein, E., Wikramanayake, E.D., Burgess, N.D., Powell, G.V.N., Underwood, E.C., D’amico, J.A., Itoua, I., Strand, H.E., Morrison, J.C., Loucks, C.J., Allnutt, T.F., Ricketts, T.H., Kura, Y., Lamoreux, J.F., Wettengel, W.W., Hedao, P., Kassem, K.R., 2001. Terrestrial Ecoregions of the World: A New Map of Life on Earth. Bioscience 51, 933.

Palm Oil Research, 2014. Statistics [WWW Document]. URL http://www.palmoilresearch.org/statistics.html (accessed 10.28.17).

Ramankutty, N., Foley, J.A., 1999. Estimating historical changes in global land cover: Croplands from 1700 to 1992. Global Biogeochem. Cycles 13, 997-1027.

Rawls, J., 1999. A Theory of Justice -Revised Edition. Harvard University Press, Cambridge, Massachusetts.

Rockström, J., Steffen, W., Noone, K., Persson, A., Stuart III Chapin, F., Lambin, E.F., Lenton, T.M., Scheffer, M., Folke, C., Schellnhuber, H.J., Nykvist, B., de Wit, C.A., Hughes, T., van der Leeuw, S., Rodhe, H., Sörlin, S., Snyder, P.K., Costanza, R., Svedin, U., Falkenmark, M., Karlberg, L., Corell, R.W., Fabry, V.J., Hansen, J., 
Ryberg MW, Owsianiak M, Clavreul J, et al. (2018) How to bring absolute sustainability into decision-making: An industry case study using a Planetary Boundary-based methodology. Sci Total Environ 634C:1406-1416. doi: https://doi.org/10.1016/j.scitotenv.2018.04.075

Walker, B., Liverman, D., Richardson, K., Crutzen, P., Foley, J.A., 2009a. A safe operating space for humanity. Nature $461,472-5$.

Rockström, J., Steffen, W., Noone, K., Persson, Å., Stuart III Chapin, F., Lambin, E.F., Lenton, T.M., Scheffer, M., Folke, C., Schellnhuber, H.J., Nykvist, B., de Wit, C.A., Hughes, T., van der Leeuw, S., Rodhe, H., Sörlin, S., Snyder, P.K., Costanza, R., Svedin, U., Falkenmark, M., Karlberg, L., Corell, R.W., Fabry, V.J., Hansen, J., Walker, B., Liverman, D., Richardson, K., Crutzen, P., Foley, J.A., 2009b. Planetary boundaries: Exploring the safe operating space for humanity. Ecol. Soc. 14, 32.

Rogelj, J., Popp, A., Calvin, K. V., Luderer, G., Emmerling, J., Gernaat, D., Fujimori, S., Strefler, J., Hasegawa, T., Marangoni, G., Krey, V., Kriegler, E., Riahi, K., van Vuuren, D.P., Doelman, J., Drouet, L., Edmonds, J., Fricko, O., Harmsen, M., Havlík, P., Humpenöder, F., Stehfest, E., Tavoni, M., 2018. Scenarios towards limiting global mean temperature increase below $1.5^{\circ} \mathrm{C}$. Nat. Clim. Chang.

Rose, A., Stevens, B., Edmonds, J., Wise, M., 1998. International Equity and Differentiation in Global Warming Policy. Environ. Resour. Econ. 12, 25-51.

Ryberg, M.W., Owsianiak, M., Richardson, K., Hauschild, M.Z., 2016. Challenges in implementing a Planetary Boundaries based Life-Cycle Impact Assessment Methodology. J. Clean. Prod. 139, 450-459.

Ryberg, M.W., Owsianiak, M., Richardson, K., Hauschild, M.Z., 2018. Development of a life-cycle impact assessment methodology linked to the Planetary Boundaries framework. Ecol. Indic. 88, 250-262.

Sandin, G., Peters, G.M., Svanström, M., 2015. Using the planetary boundaries framework for setting impactreduction targets in LCA contexts. Int. J. Life Cycle Assess. 20, 1684-1700.

Sim, S., King, H., Price, E., 2016. The Role of Science in Shaping Sustainable Business : Unilever Case Study, in: Clift, R., Druckman, A. (Eds.), Taking Stock of Industrial Ecology. Springer International Publishing, 
Ryberg MW, Owsianiak M, Clavreul J, et al. (2018) How to bring absolute sustainability into decision-making: An industry case study using a Planetary Boundary-based methodology. Sci Total Environ 634C:1406-1416. doi: https://doi.org/10.1016/j.scitotenv.2018.04.075

Heidelberg, New York, Dordrecht, London, pp. 291-302.

323

324

325

326

327

328

329

330

331

332

333

334

335

336

337

Steffen, W., Richardson, K., Rockström, J., Cornell, S., Fetzer, I., Bennett, E., Biggs, R., Carpenter, S., 2015 a. Planetary boundaries: Guiding human development on a changing planet. Science 348, 1217.

Steffen, W., Richardson, K., Rockström, J., Cornell, S.E., Fetzer, I., Bennett, E.M., Biggs, R., Carpenter, S.R., de Vries, W., de Wit, C.A., Folke, C., Gerten, D., Heinke, J., Mace, G.M., Persson, L.M., Ramanathan, V., Reyers, B., Sorlin, S., 2015b. Planetary boundaries: Guiding human development on a changing planet. Science 347, 1217.

Teah, H., Akiyama, T., San Carlos, R., Rayo, O., Khew, Y., Zhao, S., Zheng, L., Onuki, M., 2016. Assessment of Downscaling Planetary Boundaries to Semi-Arid Ecosystems with a Local Perception: A Case Study in the Middle Reaches of Heihe River. Sustainability 8, 1233.

Tuomisto, H.L., Hodge, I.D., Riordan, P., MacDonald, D.W., 2012. Exploring a safe operating approach to weighting in life cycle impact assessment - A case study of organic, conventional and integrated farming systems. J. Clean. Prod. 37, 147-153.

Vanderheiden, S., 2009. Allocating ecological space. J. Soc. Philos. 40, 257-275.

WBCSD, 2010. Vision 2050: The new agenda for business. World Business Council for Sustainable Development.

Weidema, B.P., Bauer, C., Hischier, R., Mutel, C., Nemecek, T., Reinhard, J., Vadenbo, C.O., Wernet, G., 2013. Overview and methodology, Data quality guideline for the ecoinvent database version 3. Ecoinvent Report 1(v3). The ecoinvent Centre, St. Gallen.

Wenzel, H., Hauschild, M.Z., Alting, L., 1997. Environmental assessment of products. Vol. 1 - Methodology, tools and case studies in product development. Kluwer Academic Publishers, Hingham, MA. USA. 
Ryberg MW, Owsianiak M, Clavreul J, et al. (2018) How to bring absolute sustainability into decision-making: An industry case study using a Planetary Boundary-based methodology. Sci Total Environ 634C:1406-1416. doi: https://doi.org/10.1016/j.scitotenv.2018.04.075

342 Windolph, S.E., Harms, D., Schaltegger, S., 2014. Motivations for corporate sustainability management:

343 Contrasting survey results and implementation. Corp. Soc. Responsib. Environ. Manag. 21, 272-285.

344 Wolff, A., Gondran, N., Brodhag, C., 2017. Detecting unsustainable pressures exerted on biodiversity by a 345 company. Application to the food portfolio of a retailer. J. Clean. Prod. 166, 784-797.

346 Yeh, W.W.-G., 1986. Review of Parameter Identification Procedures in Groundwater Hydrology: The Inverse 347 Problem. Water Resour. Res. 22, 95-108. 